\title{
Address Forms of English: Rules and Variations
}

\author{
Xiaomei Yang \\ Qingdao University of Science and Technology, Qingdao, China \\ Email: Lindateacher@tom.com
}

\begin{abstract}
Address forms are a social phenomenon. In English, there are general rules of their usage, but because of a series of social factors, they vary in different situations. In this article, we 1 roughly discuss the rules of address forms, and list some factors that may affect the address forms. To address others appropriately needs the good mastery of the knowledge of the two sides.
\end{abstract}

Index Terms - address forms, rules, variations, social factor

\section{INTRODUCTION}

One of the earliest sociolinguistic studies of speech behavior among speakers of English concerns the way people in the English speaking countries address one another. Forms of address are important for effective and successful communication and have long been considered a very salient indicator of status of relationships. One can use different forms of address to show his respects or fondness towards other people, or to insult or depreciate them. How to address people appropriately needs the taking of several factors into consideration, such as the social status or rank of the other, sex, age, family relationship, occupational hierarchy, transactional status, race or degree of intimacy. There do exist general rules of address forms in English, but because address forms are a social phenomenon, it varies on different occasions and the rules do not always take effect, just as Philipsen and Huspek said: "Personal address is a sociolinguistic subject par excellence. In every language and society, every time one person speaks to another, there is created a host of options centering around whether and how persons will be addressed, named, ... to those who interpret them, are systematic, not random. Such systematicity in language behavior, whether of use or interpretation, is universal, although what elements comprise the personal address system and what rules govern its deployment, vary across contexts. And such variation in structure is, according to the extant empirical literature, correlated with social ends and social contexts of language use. From this view, personal address is a systematic, variable, and social phenomenon, and these feature of if make it a sociolinguistic variable, and social phenomenon, and these features of it make it a sociolinguistic variable of fundamental importance." (Philipsen and Huspek 1985:94)

\section{GENERAL RULES OF FORMS OF ADDRESS}

Despite of its occasional inefficiency, we will first look at the general rules of address forms. An English or American person can be addressed by his name, his title his name plus his name, or by nothing at all, that is, no-naming form or $\Phi$.

\begin{tabular}{|l|l|}
\hline 1 Name & Examples \\
\hline (1) full name & "A rise! Horatio Fliyd Beanish, do you know we are at war? \\
\hline (2) first name & “'They are on your desk, Robert" \\
\hline (3) nickname & "Jonny, there's something I have to tell you." \\
\hline 2 Title & Examples \\
\hline (1) title concerning family relationship & "All right now, children! Outside for your walk, father's orders. \\
\hline (2) title of occupation & "Operator, could you please put through a call to Copenhagen?" \\
\hline (3) title of rank & "You are right, captain." \\
\hline (4) honorifics & "Your Royal Highness, twenty-four hours. They can't be blank. \\
\hline (5) other titles & "Oh, darling." / You dogs!" / What do you want, fellow?" \\
\hline 3 Title plus name & Doctor Smith \\
\hline 4 No-naming or $\Phi$. & " Good morning" \\
\hline
\end{tabular}

These address forms can be found in daily communication, both in oral and written forms. In addition to causing other people's attention, address forms have other important social functions, such as to show respect, to show intimacy, to honor or to humiliate other people. In the following part, we will mainly discuss the application of address forms in some specific social environments. 


\section{VARIATIONS OF ADDRESS FORMS}

\section{A. Region Difference}

There are differences even in the way different regions in the United States use different forms of address. For example, the use of a person's first manes in North America does not necessarily indicate friendship or power. First names are required among people who work closely together, even though they may not like each other at all. First names may even be used to refer to public figures, but contemptuously as well as admiring.

The various use of address forms sometimes merely serve as a marker of regional difference, but sometimes it is enough to cause miscommunication. Wolfson and Manes (1978) reported that the address form ma'am has different meanings in the southern part of the United States than it has elsewhere. In the South, the term ma'am is often used a substitution for the formula "I beg your pardon?" or "pardon?" in asking someone to repeat what he has said or to explain something. The contrast in the use of the two forms is exemplified in the following conversation.

(1) A: Could you tell me how late you're open this evening?

B: Ma'am?

A: Could you tell me how late you're open this evening?

B: Until six.

In addition, it was found that the phase "Yes, Ma'am" is often used instead of "You're welcome" as a response to "Thank you". For example:

(2) A: Could you tell me how late you're open this evening?

B: Until five-thirty.

A: Thank you very much.

B: Yes, ma'am. (Wolfson 1989:80)

Not only is the form "ma'am" gives different meanings in the South, it is also used in very different social contexts than elsewhere in the country. In the northeast, for example, "ma'am " was found to occur between strangers and, to a lesser extent, from lower to upper status speakers. In the South, however, it was found that the term was used not only to strangers but also to acquaintance and even intimates. Thus, graduate students at the University of Virginia were heard to be addressed as "ma'am" by their male professors, female colleagues were given this address form by their male colleagues, and husbands were even heard to use this term to their own wives. While it is unlikely that women from other parts of the country would become offended if they were addressed as "ma'am" in situations where they were unaccustomed to it, it is possible that southern women would misunderstand the absence of this form where they were used to expecting it, and would therefore regard non-southern speakers as rude or lacking in respect for women.

\section{B. Sex Variation}

We all know that address forms of English is asymmetrical, that is, we can use "Mr." to address all the male, but we use different terms to address the female who are unmarried (Miss) and who are married (Mrs.). Another noteworthy phenomenon concerning address forms among speakers of American English is the way in which strangers in public situations address unknown women by terms of endearment. Women in America are often addressed with a good deal less respect than are men. Those women are mostly women in service encounters. The commonly used terms of endearment are dear, love, honey, sweetheart, but some others are unusual, such as cake, peach, tomato, dish, cheese, etc. For example:

(3) (From The love song of J. Alfred Prufrock by Eliot)

Shall I part my chair behind?

Do I dare to eat a peach?

The fact that women are addressed publicly by nonreciprocal terms of endearment, no matter what their age or status, may be seen as a sign that female are generally held in less respect than are males in American society.

There are some other differences between address forms of male and female. R. B. Rubin, in a study of address forms for male and female professors, found that female professor, especially those in the 26 to 33 age group, were addressed by first name much more often than their male colleagues. Rubin also points out that female students use familiar terms more often than male students. Another study by McConnell-Ginet (1978) found that women in general American society had at their disposal a much smaller number of address forms than did men. That is, while men seem to be free to address other men, especially those whose occupation involve driving taxis or bartering, by use of such terms as Buddy or Mac, social rules for women preclude such usage. Women are addressed by terms of endearment, or nothing at all.

\section{Race Variation}

In the United States, the white have often used naming and addressing practice to put blacks in their place. Hence the odious use of "Boy" to address the blacks is well-known, as is shown in the following example:

(4) A black physician, Dr. Poussaint, was stopped by a white policeman in a southern town in the United States and was questioned:

"What's your name, boy?"

"Doc. Poussaint, I'm a physician." 
"What's your name, boy?"

"Alvin"

In this conversation, the policeman insulted Doc. Poussaint three times. For two times he used the racial discriminating address form "boy", another was that he was not satisfied with the physician's answer "Doc. Poussaint" and continued to ask the "name" of the physician. By being addressed "boy", Doc. Poussaint experienced a feeling of "profound humiliation".

The asymmetrical use of names was also a part of the system. White people addressed the blacks by their first names in situations that required them to use title, or title and last names, if they were addressing whites. There was a clear racial distinction in the practice. According to Johnson, one consequence of this practice was that:

Middle and upper class Negro women never permit their first names to be known... The wife of a well-to-do Negro businessman went into a department store in Atlanta to enquire about an account. The clerk asked her first name, and she said "Mrs. William Jones". The clerk insisted in her first name, and when she refused to give it, declared that the business could not be completed without it. It was a large account, and the manager, to whom appeal was made, decided that "Mrs." was simply "good business" and not "social equality" (Johnson 1982).

In this case, "good business" overrode the desire to reinforce the social inequality that would have resulted from the woman's giving the salesclerk the information requested and then the inevitable use of that first name alone by the clerk requested and not "social equality". The special or asymmetrical use of address forms indicates racial discrimination in America.

\section{CONCLUSION}

Address forms are a key to the understanding of social concepts and human relationship in a society. Different degrees of status difference or intimacy need the choosing of different forms of address. The connotations of English address forms are all different and each gets different stylistic or emotional implications, and rules for their usage are quite complex, and they vary from class to class, age group to age group, place to place. In addition, they are also affected by a series of social factors. How to address people appropriately needs not only a good understanding of the rules, but also the taking of all relevant factors into consideration.

Address form can also be a marker of regional difference, sex or racial discrimination, social class difference, etc. It is an important aspect of social behavior. In English teaching, the teacher should be aware of the importance of the choosing of proper address forms. The misuse of a title can sometimes put other people in an awkward situation, even offend them if we keep ignoring its important function. A thorough study and good mastery of address forms is necessary for intercultural communication.

\section{REFERENCES}

[1] Ervin-Tripp, S. (1972). On sociolinguistic rules: Alternation and co-occurrence. In Directions on Sociolinguistics. New York: Runehart \& Winson.

[2] Johnson, K. (1982). Communicative Syllabus Design and Methodology. Oxford: Pergamon.

[3] McConnell-Ginet, S. (1978). Address forms in Sexual politics. In Women's Language and Style, eds. D. Butturff and E. L. Epstein, Akron. OH: University of Akron Press.

[4] Philipsen, G. and M. Huspek, (1985). A Bibliography of Sociolinguistic studies of Personal Address. Anthropological Linguistics 27(1): 94-101.

[5] Trudgill, P. (1983). Sociolinguistics: An Introduction to Language and Society. Penguin Books Ltd. England.

[6] Wardbaugb, R. (1986). An introduction to sociolinguistics. Basil Blackwell World Publishing Corp.

[7] Wolfson, N. (1989). Perspectives: Sociolinguistics and TESOL. Newbuky house Publishers.

[8] Wolfson, N and J. Mane. (1978). Don't dear me. Working papers in sociolinguistics. Austin, TX: SEDL.

Xiaomei Yang was born in Qingdao, China in 1975. She received her M.A. degree in linguistics from Qufu Normal University, China in 2000.

She is currently a lecturer in the College of Foreign Languages, Qingdao University of Science and Technology, Qingdao, China. Her research interests include linguistics and second language acquisition. 